\title{
Foreign Direct Investment and the Nigerian Economy
}

\author{
Kabir Haruna Danja
}

Kampala International University, Uganda School of Economics and Applied Statistic

\begin{abstract}
Most economic rationale for granting special incentives for attracting Foreign Direct Investment (FDI) is based on the belief that FDI bridges the 'idea gaps' between rich and the poor nations in addition to the generation of technological transfers and spillovers. The study examines the applicability of FDI and the Impact they makes to the Nigerian economy hypothesis using empirical evidence from Nigeria were used. Empirical literature however finds controversial, the effects of FDI on productivity. In some literatures, it was revealed that multinational corporations are highly adaptive social agents and therefore, the degree to which they can help in improving economic activities through FDI will be heavily influenced by the policy choice of the host country. Data were collected for the period of more than 30 years. For analyzing the data both econometric and statistical method were applied. In order to evaluate the relationship between FDI and major economic indicators such as GDP, IIP and GFCF ordinary least square was used. The model revealed a positive relationship between FDI and those variables but FDI has not contribute much to the growth and development of the Nigerian economy and was evidence due to repatriation of profits, contract fees, and interest payment on foreign loans. The study therefore recommends human capacity building, infrastructural facilities and strategic policies to attract FDI inflow.
\end{abstract}

Keywords Foreign, Direct, Investment, Economy

\section{Introduction}

Foreign Direct Investment (FDI) from developing countries has risen sharply over the past two decades. This has been noted by several authors since the early 1980s (Lall, 1983; Kumar, 1995; Page 1998; Aykut and Ratha, 2003, and UNCTAD, 2004). Most FDI has been by Asian firms establishing footholds in other Asian countries but there has also been investment in developed countries such as the EU. Total investment by developing countries began to raise from about $1 \%$ of total foreign investment flows in the late 1970 s to $4 \%$ in the mid 1980 s and $6 \%$ by 1990 , and after a peak in the 1990s before the Asian crisis, has remained around $6-7 \%$ of the total. The rise coincided with the reduction in the large differential between developing and developed country growth found in the 1970s and with a reduction, in some cases a reversal, of relative protection in developed and developing countries (revival of protection in the developed countries; liberalisation in the developing). It also coincided with some reduction in the growth of outflows to developing countries, suggesting that the same influences were affecting flows in both directions. South-South flows are estimated (as a residual, and noting challenges regarding data and methodology) to have risen from 5\% in 1994 to $30 \%$ in 2000 of the total FDI inflows to developing countries, see Aykut and Ratha (2003).

* Corresponding author:

khdanja@yahoo.co.uk (Kabir Haruna Danja)

Published online at http://journal.sapub.org/economics

Copyright (C) 2012 Scientific \& Academic Publishing. All Rights Reserved
Nigeria is one of the economies with great demand for goods and services and has attracted some FDI over the years. The amount of FDI inflow into Nigeria has reached US $\$ 2.23$ billion in 2003 and it rose to US\$5.31 billion in 2004 (a $138 \%$ increase) this figure rose again to US $\$ 9.92$ billion (an $87 \%$ increase) in 2005 . The figure however declined slightly to US\$9.44 billion in 2006 (LOCOmonitor.com). The question that comes to mind is, do these FDIs actually contribute to economic growth in Nigeria? If FDI actually contributes to growth, then the sustainability of FDI is a worthwhile activity and a way of achieving its sustainability is by identifying the factors contributing to its growth with a view to ensuring its enhancement. Again, most studies on FDI and growth are cross-country studies. However, FDI and growth debates are country specific. Earlier studies (for instance, Otepola, 2002; Oyejide, 2005; Akinlo; 2004) examines only the importance of FDI on growth and the channels through which it may be benefiting the economy. This study however examines the contributions of FDI to growth. In addition, analyze the endogeneity case using the causality test. It also empirically investigates the determinants of FDI flow in Nigeria.

Overall, empirical evidence in the last few decades indicates that FDI flows have been growing at a pace far exceeding the volume of international trade. Between 1975 and 1995 , the aggregate stock of FDI rose from $4.5 \%$ to $9.7 \%$ of world GDP, with sales of foreign affiliates of multinational enterprises substantially exceeding the value of world exports (Barrell and Pain, 1997). The United Nations Conference on Trade and Development, UNCTAD (2007) reports that FDI flow to Africa has increased from $\$ 9.68$ billion in 
2000 to $\$ 1.3$ trillion in 2006. The UNCTAD World Investment Report 2006 shows that FDI inflow to West Africa is mainly dominated by inflow to Nigeria, who received $70 \%$ of the sub-regional total and $11 \%$ of Africa's total. Out of this Nigeria's oil sector alone receive $90 \%$ of the FDI inflow.

Aggregate output growth measured by the gross domestic product (GDP), according to the Central Bank of Nigeria (CBN) 2007, economic report for third quarter of 2007, was estimated at 6.05 per cent, compared with 5.73 per cent in the second quarter. The growth was driven by the nonoil sector which was estimated at 9.47 per cent. This growth was driven mainly by major agricultural activities such as yam, Irish and sweet potatoes, groundnuts and maize.

Various classifications have been made of foreign direct investment (FDI). For instance, FDI has been described as investment made so as to acquire a lasting management interest (for instance, $10 \%$ of voting stocks) and at least $10 \%$ of equity shares in an enterprise operating in another country other than that of investors' country (Mwillima, 2003; World Bank, 2007). Policymakers believe that foreign direct investment (FDI) produces positive effects on host economies. Some of these benefits are in the form of externalities and the adoption of foreign technology. Externalities here can be in the form of licensing agreements, imitation, employee training and the introduction of new processes by the foreign firms (Alfaro, 2006). According to Tang, Selvanathan and Selvanathan (2008), multinational enterprises (MNEs) diffuse technology and management know-how to domestic firms. When FDI is undertaken in high risk areas or new industries, economic rents are created accruing to old technologies and traditional management styles. These are highly beneficial to the recipient economy. In addition, FDI helps in bridging the capital shortage gap and complement domestic investment especially when it flows to a high

Risk areas of new firms where domestic resource is limited (Noorzoy, 1979).

The favourable economic environment has made some countries in SSA increasingly attractive as destinations for private capital inflows. Net private capital inflows reached record levels in 2007, led by strong FDI inflows. However, the bulk of FDI is still focused on a few countries and targeted mainly at extractive industries, particularly the petroleum sector, based on evidence from cross 3 border mergers-and-acquisition related inflows, an important fraction of gross FDI inflows. But, deposit outflows from some oil exporters notably Libya, Nigeria, and Russia displayed some of the highest correlations, while for others including Saudi Arabia and other Middle Eastern oil exporters, the correlations were only modest. Libya, Nigeria, and Russia also accounted for one-half of all deposit outflows from oil- exporting countries, and in each of these countries deposit outflows accounted for one-half or more of total gross capital outflows. These huge capital outflows are linked mainly to extractive FDI and calls to question the ability of FDI to drive growth effectively in these countries.

\section{Theoretical Explanations of Developing Country FDI}

\section{Explaining developing country foreign investment}

Neo-classical researchers regard FDI and international capital flows as closing the savings gap in developing countries (e.g. Chenery and Bruno, 1962). We would expect capital to flow from capital rich to capital poor countries, as is suggested by developments in the Heckscher-Ohlin approach to trade by Mundell (1957), because capital is scarce in developing countries which should lead to profitable investment opportunities for capital in developing countries. On this view there should be no outflows from Africa.

However, FDI represents control of production as well as a flow of capital, and it is influenced by other factors as well. In the traditional trade approach, trade and FDI might be seen as substitutes, but as other factors affect FDI , such as technology and firm-specific assets, they may also be complements (Markusen, 1984 and 1995). Examples of firmspecific assets are brand names (acquired through advertising) or firm specific knowledge (acquired through R\&D). On this view African outward FDI would still be limited, because they do little research and spending on advertising, with the possible exception of South Africa.

Recognising that there are other reasons for FDI than differences in factor endowments and factor prices, trade economists have begun to embrace increasing returns, imperfect competition and product differentiation in addition to the traditional comparative advantage paradigm and where multinationals have been incorporated and made endogenous. The first attempts were by Helpman (1984) who integrated vertical multinationals and Markusen (1984) who integrated horizontal multinationals into the trade theory. Vertical multinationals separate production geographically into different plants to intra-industry trade. Horizontal multinationals are multi-plant firms selling similar products in different locations. Markusen (1997) presents a unified approach to vertical and horizontal multinationals. Horizontal Multinational Enterprises (MNEs) dominate if nations are similar in size and relative endowments and if transport costs are high. Vertical MNEs appear with headquarters in the skilled labour abundant country, provided that transport costs are high enough. National firms dominate if both trade costs are small and the home market is large enough: in this situation it makes sense to incur the fixed costs of setting up only one plant, from where to export. Within this framework it can be shown that trade and investment liberalisation are not substitutes and the two taken together may lead to a reversal in the direction of trade. Carr et al. (2001) provides a good empirical test of the framework, clearly showing the complexity and non-linearity's affecting FDI and hence the relationship between trade and FDI. On this view, African outward FDI (particularly intra-Africa) will grow, but only 
in the future as incomes in Africa rise and their economic structures become similar.

International business economists (see Dunning, 1993) have explained the emergence of TNCs using an eclectic paradigm for FDI, the Ownership-Location-Internalisation (OLI) framework. Multinationals need to have some firm specific asset that differentiates them from domestic firms to compensate for the extra costs in terms of local knowledge that a foreign firm must incur to operate in foreign markets. The firm specific asset is called an ownership $(\mathrm{O})$ advantage. Multinationals should also have an internalization (I) advantage to internalize business contacts, and not to outsource. The reason why a multinational invests in one country but not in another depends on the country's location advantage (L). The OLI framework explains FDI on the basis of ownership-specific advantages of the firm, internationalization incentives and location advantages. Dunning then defines four types of TNCs:

- Market-seeking (TNCs that serve market through investment rather than through exports)

- Efficiency-seeking (e.g. TNCs using low labour costs)

- Natural resources-seeking

- Strategic asset seeking (seeking technology, skills or take over brand names)

Using this classification, African investors are more likely to invest in order to seek markets or for strategic reasons, and especially the latter is more likely to be out of Africa. African's are less likely to invest outside Africa for efficiency reasons (it has relatively low wages, though there is disparity as we will note later) or for natural resources (Africa has an abundance of natural resources). We also need to take into account policy factors (trade, investment, and privatization) as these have changed dramatically within Africa.

Aykut and Ratha (2003) also discuss factors behind the rise in South-South flows, and distinguish between pull and push factors but do not deal with the African context (with the exception of South Africa).

Push factors include:

- Rising wealth in emerging markets

- Rising cost of labour and non-tradable

- breaking up domestic monopolies

- New technology and communications improved information sharing and reduced transaction costs

- Strategic, desire to procure inputs such as oil

- Capital account liberalisation regarding outward FDI, changes in trade barriers, regional trade agreements, and government policies encouraging outward FDI.

Pull factors include:

- Large and growing markets

- Geographic proximity and ethnic and cultural ties

- Supply of cheap labour

- Abundance in raw materials

- Incentives in host countries, preferential treatment of foreign companies, and export markets through preferential treatment.

In this paper we will attempt to explain changes in outward FDI by Africa through the lens of the following factors:
1. Relative growth rates. If Africa is now growing less slowly than other regions, then logically speaking investors would take advantage of that; or African countries with faster growth rates should receive more African FDI than African countries with slower growth (e.g. due to conflict).

2. Relative market size. The size of Africa's markets is relatively small, individually and to some extent for Africa as a whole. There are large markets outside Africa which can be served by FDI (or trade). Outward investment should be relatively high, and within Africa should go to larger economies

3. Level and changes in relative protection. Tariff-jumping is said to be one motive behind FDI (Brazil to Europe, also from Asia to Europe), and with tariffs for many African countries higher than in developed countries, this could lead to African outward FDI in other African countries. But the growing importance of regions in Africa which have reduced intra-African barriers could have reduced this incentive. Although the high cost of transport in intra-African trade (estimated at equivalent to pre-liberalisation tariffs) may mean that there is still an incentive to invest near to markets.

4. Regional influences. Regionalisation both in Africa and in the potential destinations for its investment increases the size of markets, increasing incentives, but may reduce differences in growth rates, costs, or policies among neighbours, reducing incentives for investment.

5. Changes in policy and laws on inward and outward investment. Many African countries have seen changes in investment policy, including bilateral and regional investment treaties, and privatisation policy, almost all towards a more liberal stance towards FDI. This should have affected intra-Africa FDI

6. Changes in relative costs of production. If the level of wages or user costs of capital is higher in Africa, or if they were growing more rapidly than outside Africa this would lead to more outward African FDI.

7. Changes in strategy to obtain better access to technology, distribution channels or other inputs. This would lead to developing country outward FDI for competitiveness reasons (Kumar, 1995). Firm-specific assets, such as technology or management skills, may be emerging in some African firms, increasing their propensity to invest abroad.

8. Region specific knowledge: common characteristics are a well-studied positive influence on trading patterns, because they lower the information costs of entering new markets; this may also give African companies an advantage over non-African countries in African destinations. This is particularly important in Africa because conventional risk rating and country evaluation is less common and less comprehensive for African countries. Only South Africa is regularly rated, with some coverage at Mauritius and Botswana (African Development Report 2003).

There are also general potential influences on African investment which could help explain its direction

9. The links of complementarities with trade, suggesting that as African trade expands moves into markets, investment could follow. 
10. The possibility that some African countries will emerge as particularly active in foreign investment, as some have done in Europe and Asia: the shares of FDI are much more concentrated than those of trade suggesting that there are special characteristics that make some countries more likely to be major investors

11. Foreign investment requires firms able to negotiate the differences in economic and legal conditions in the foreign country or put differently, with prospective sales or cost saving sufficiently large to justify incurring the costs.

Normally, such firms are larger than average. Firms must reach the critical size on the basis of home markets: this is likely to be a constraint in small economies (and most African economies are still very small compared to those of the major world investors), but as the economies grow the number of potential TNCs will increase. The more barriers to investment come down, both direct barriers and differences in company legislation and standards, either within regions or in general, the smaller the required size for a firm to be internationally competitive.

Cost factors have reduced the relative attractiveness of developing countries, and Africa in particular, as destinations for foreign investment, although market factors have probably increased it. The importance of information and the relative lack of information about Africa outside Africa both suggest that any increase in investment in Africa may be preferentially by African investors. Policy presents fewer barriers (but perhaps also reduced incentives

\section{Review Literatures}

Nunnenkamp and Spatz (2003) however criticized the view that developing countries should draw on FDI to create economic development. They concluded that the growth impacts of FDI are ambiguous because of highly aggregated FDI data. By disaggregating FDI and considering the compatibility of different types of FDI on economic conditions prevailing in the host country, the positive growth effects of FDI are doubtful. Host country and industry characteristics as well as the interplay between both sets of characteristics determine the growth impact of FDI in developing nations. Alfaro et. al. (2006) analyzed the role of local financial markets in enabling FDI to promote growth through backward linkages. They asserted that to operate intermediate firms in the goods sector, the entrepreneurs require upfront capital investments. The more developed the local financial markets is, the easier it is for credit constrained firms to operate. The increase in the varieties and quantities of intermediate goods, leads to positive spillovers to the final goods sector. Due to this, the financial markets ensure the backward linkages between foreign and domestic firms to turn into FDI spillovers. Their calibration results indicate that holding foreign presence constant, financially well developed economies perform almost as twice as economies with poor financial markets in term of growth. FDI contributes more in an economy with well developed financial system than in an economy with less developed financial system. Lastly, local conditions such as market structure, human capital are also important to generate a positive effect of FDI on economic growth.

There are a number of ways through which Trade flows and FDI can be linked. Goldberg and Klein, (1998) asserted that FDI may encourage export promotion, import substitution, or greater trade in intermediate inputs which often exist between parent and affiliate producers. The orientation of most investments by multinational firms is towards exports and this may most likely serve as a catalyst for the integration of the FDI host economy to a global production network in sectors in which it may formerly have had no industrial experience (OECD, 1998). Rodriguez Clare (1996); Calderón, Mortimore and Peres (1996) argue that the very nature of the activities of multinational enterprises in Mexico could encourage the expansion of its industrial exports. These studies clearly indicate that FDI could be associated with export trade in goods, and the host country may enjoy an FDI led export growth. Goldberg and Klein $(1998,1999)$ do not find evidence to support a significant link between FDI and aggregate exports in Latin America. According to them, the trade-promoting effects of FDI appear to be weak or insignificant with regard to Latin American trade with the United States and Japan. Their results also failed to find a systematic linkage between sectoral trade and FDI in Latin America.

Romer (1993) argues that idea gaps exist between the rich and poor countries and foreign investment can ease the transfer of technology and business understanding of the poorer countries. Based on this view, FDI can have a spillover on all firms thereby boost the productivity of the entire economy. Boyd and Smith (1992) however argued to the contrary. According to them, FDI can affect resource allocation and growth negatively where there is price distortion, financial, trade and other forms of distortions existing prior to FDI injections. Wheeler and Mody (1992) also supports the view of Boyd and Smith (1992).

According to Wheeler and Mody (1992), infrastructure enhances FDI's contributions by reducing their operating costs and increasing the productivity of investments. In other words, the growth impact of FDI is not automatic but tied to certain levels of infrastructure and economic performance.

Edozien (1968) discusses the linkage effects of FDI on the Nigerian economy and submits that these have not been considerable and that the broad linkage effects were lower than the Chenery-Watanabe average (Chenery and Watanabe, 1958). Oseghale and Amonkhienan (1987) found that FDI is positively associated with GDP, concluding that greater inflow of FDI will spell a better economic performance for the country. Ayanwale (2007) investigated the empirical relationship between non-extractive FDI and economic growth in Nigeria. Using OLS estimates, he found that FDI has a positive link with economic growth but cautioned that the overall effect of FDI on economic growth may not be significant. Herzer et al (2006) using a bivariate VAR modeling technique, found evidence of a positive FDI-led growth for Nigeria, Sri Lanka, Tunisia, and Egypt; and based on weak exogeneity tests, a long-run causality between FDI 
and economic growth running in both directions was found for the same set of countries. A slight difference from this result is observed in Okodua (2009) who examined the sustainability of the FDI-growth relationship in Nigeria. Using the Johansen cointegration framework and a multivariate VAR within a vector error correction model, found evidence of a long-run equilibrium relationship between economic growth and FDI inflows. The study also revealed a unidirectional causality from FDI to economic growth.

Akinlo (2004) investigates the impact of FDI on economic growth in Nigeria using data for the period 1970 to 2001. His error correction model (ECM) results show that both private capital and lagged foreign capital have small and insignificant impact on economic growth. This study however established the positive and significant impact of export on growth. Financial development which he measured as M2/GDP has significant negative impact on growth. This he attributed to capital flight. In another manner, labour force and human capital were found to have significant positive effect on growth.

The generation of productivity spillovers is one possible channel through which FDI can affect growth. Some earlier studies found evidence that FDI has led to significant positive spillover effects on the labour productivity of domestic firms and on the rate of growth of domestic productivity in Mexico [Blömstrom and Persson (1983), Blömstrom (1986), Blomström and Wolf, (1994)]. However, Kokko, Tansini and Zejan (1996) cautioned in the case of Mexico and Uruguay, that spillovers are difficult to identify in industries where foreign affiliates have much higher productivity levels than local firms. De Gregorio (2003) contributes to the debate on the importance of FDI by noting that FDI may allow a country to bring in technologies and knowledge that are not readily available to domestic investors, and in this way increases productivity growth throughout the economy. Dolan and Tomlin (1980) found that FDI flows were positively associated with growth of per capita income but that the stock of FDI had a negative effect on growth. This result is supported by Saltz (1992) who confirms a negative stock effect for a sample of 75 developing countries for the period 1970-80. Balasubramanyam, Salisu, and Sapsford (1996) analyses how FDI affects economic growth in developing economies. Using cross-sectional data and OLS regressions, they found that FDI has a positive effect on economic growth in host countries with an export promoting strategy but not in countries using an import substitution strategy.

Tang, Selvanathan and Selvanathan (2008) explored the causal link between FDI, domestic investment and economic growth in China between 1988-2003 using the multivariate VAR and ECM. Their results indicate that there is a bi-directorial causality between domestic investment and economic growth, while there is single-directional causality from FDI to domestic investment and to economic growth. They concluded that there is a higher level of complementarity between FDI and domestic resources. Studies on FDI-growth issues in Nigeria include Oyejide (2005) which provided conceptual framework for the analysis of the macroeconomic effects of volatile capital flows. It concluded that capital flows have their pros and cons. This however depends on the initial conditions of the developing economy concerned. It can stimulate growth of the real sectors when the initial conditions are right. It could retard growth however, due to macroeconomic shocks that could undermine the stability of real sector and impose higher adjustment cost on the economy. The paper therefore recommends capacity building as a way of maximizing benefits and minimizing risks from capital flows. Otepola (2002) examines the importance of foreign direct investment in Nigeria. The study empirically examined the impact of FDI on growth. He concluded that FDI contributes significantly to growth especially through exports. This study recommends a mixture of practical government policies to attract FDI to the priority sectors of the economy.

A number of studies on the FDI-growth nexus in Nigeria exist in the literature. For example, Otepola (2002), in a work on FDI and economic growth in Nigeria reported a low level of existing human capital suggesting that the human capital (labour) available in Nigeria is not FDI inducing. Akinlo (2004) noted that export, labour, and human capital are positively related to economic growth in Nigeria. Ayanwale and Bamire (2001) assess the influence of FDI on firm level productivity in Nigeria and report a positive spillover of foreign firms on domestic firm's productivity. Oyinlola (1995) conceptualized foreign capital to include foreign loans, direct foreign investments and export earnings. Using Chenery and Stout's two-gap model (Chenery and Stout, 1966), he concluded that FDI has a negative effect on economic development in Nigeria. Adelegan (2000) explored the seemingly unrelated regression model to examine the impact of FDI on economic growth in Nigeria and found out that FDI is pro consumption and pro-import and negatively related to gross domestic investment. Akinlo (2004) found that foreign capital has a small and not statistically significant effect on economic growth in Nigeria. Aluko (1961), Brown (1962) and Obinna (1983) report positive linkages between FDI and economic growth in Nigeria.

\section{Model Specification}

The following variables are used in making the model.

FDI Foreign Direct Investments

GFCF Gross Fixed Capital Formation

GDP Gross Domestic Product

IIP Index of Industrial Production

Therefore models will be:

$$
\begin{gathered}
\text { GPD }=\beta 0+\beta 1 \text { FDI }+u \\
\text { GFCF } \beta 0+\beta 1 \text { FDI }+u \\
\text { IIP }=\beta 0+\beta 1 \text { FDI }+u
\end{gathered}
$$

These models, which are used in gauging and assessing the performance of the economy, make the economic indicators functions of the level of cumulative foreign direct investment. If we assume a linear relationship (logarithm), then the model equations become.

$$
\begin{aligned}
\log \text { GPD } & =\beta 0+\beta 1 \operatorname{Iog} \text { FDI }+u \\
\log \text { GFCF } & =\beta 0+\beta 1 \log \text { FDI }+u
\end{aligned}
$$




\section{FINDINGS}

$$
\log \operatorname{IIP}=\beta 0+\beta 1 \log \mathrm{FDI}+\mathrm{u}
$$

From the model

$\log$ GDP $=\beta 0+\beta 1$ FDI

$\log$ GDP $=0.159+1.237 \log$ FDI

Standard Error $(\mathrm{Se})=0.158$

Correlation coefficient $(r)=0.99$

$\mathrm{t} 1=1.03$

$\mathrm{t} 2=0.037$

The first important thing about the above result is that GDP is positively related to FDI. The responsiveness of GDP to FDI to 1.237 indicates that a one percent increase in foreign direct investment leads to a more than proportionate increase of 1.24 percent in GDP.

A correlation coefficient of 0.99 indicates a very strong relationship between economic growth (measured by GDP) and foreign direct investments, thus leading to the rejection of our alternative hypothesis and acceptance of our null hypothesis, which states that there is a relationship between FDI and economic growth.

Also, a test of the significance of the intercept and gradient of our model is found to be statistically significant through a test of standard error. Thus given that:

$$
\mathrm{H} 0: \mathrm{a}=0
$$

$$
\mathrm{H1}: \mathrm{a}+0 \text {, for significance of intercept }
$$

And

$$
\mathrm{H} 0=0
$$

$\mathrm{H} 1: \mathrm{B}+0$, for significance of gradient.

For $\mathrm{t} 1$ since the computed value of 1.02 is less than 2.042 (value from $\mathrm{t}$ table), we reject $\mathrm{H} 1$ and accept $\mathrm{H} 0$ which states that there is a relationship between FDI and economic growth. For $\mathrm{t} 2$ since the computed value of 0.037 is less than 2.042 (value from $\mathrm{t}$ table), we reject $\mathrm{H} 1$ and accept $\mathrm{H} 0$ which states that there is a relationship between FDI and economic growth.

From the model

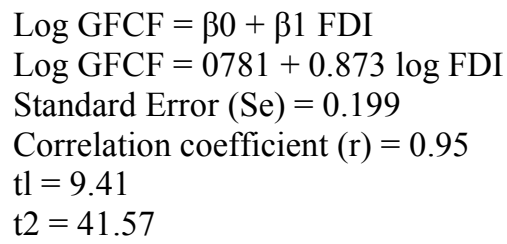

The results from this model shows that there exist a direct functional relationship between foreign direct investment and standard of living, such that the elasticity of gross fixed capital formation with respect to foreign direct investment is 0.873 .

A correlation coefficient of 0.95 indicates a very strong relationship between foreign direct investment and gross fixed capital formation (which could be used as a measure of standard of living). Also, a test of the significance of the intercept and gradient of our model is found to be statistically significant through a test of standard error. Thus given that

$$
\mathrm{H} 0: \mathrm{a}=0
$$

$$
\mathrm{H} 1: \mathrm{a}+0 \text {, for significance of intercept }
$$

And

$$
\mathrm{H} 0: \mathrm{B}=0
$$

$\mathrm{H1}$ : $\mathrm{B}+0$, for significance of gradient

For t1 since the computed value of 9.41 is greater than 2.042 (value from 1 table), we reject $\mathrm{H} 0$ and accept $\mathrm{H}$, which states that the inflow of foreign direct investment has not affected the standard of living of Nigerians. For 12 since the computed value of 41.57 is greater than 2.042 (value from $t$ table), we reject $\mathrm{H} 0$ and accept $\mathrm{H}$, which states that the inflow of FDI has not affected the standard of living of Nigerians.

The above results show a positive relationship between foreign direct investment and industrial production. The elasticity of the index of industrial production with respect to foreign direct investments of 0.14 indicates that one percent increase in foreign direct investment will lead to fourteen percent increase in the level of industrial output.

The coefficient of explanatory variable of foreign direct investment is also significant, statistically at 8.5 percent. The correlation coefficient of 0.78 shows high positive relationship between foreign direct investment and index of industrial output.

Also, a test of the significance of the intercept and gradient of our model is found to be statistically significant through a test of standard error. Thus given that:

$$
\text { Ho: } \mathrm{a}=0
$$

$\mathrm{H1}: \mathrm{a}+0$, for significance of intercept

And

$$
\mathrm{H} 0: \mathrm{B}=0
$$

$\mathrm{H} 1$ : $\mathrm{B}+0$, for significance of gradient.

For t1 since the computed value of 936 is greater than 2.042 (value from $\mathrm{t}$ table), we reject $\mathrm{H} 0$ and accept $\mathrm{H}$, which states that the inflow of foreign direct investment is not associated with the rate of increase in index of industrial production. For $\mathrm{t} 2$ since the computed value of 7.05 is greater than 2.042 (value from $t$ table), we reject $\mathrm{H} 0$ and accept $\mathrm{H} 1$

\section{Conclusions}

In conclusion it is clear that Nigerian economy needs major private sector investment in almost all aspect of the economy that can industrialize the whole economy. Therefore, Nigeria's foreign investment policy should gear towards attracting and encouraging inflows of foreign capital investment through stable economic programmes. Also government should embarked on development of indigenous technology and entrepreneurial capabilities because foreign investment cannot contribute much to the economic development of Nigeria if it is directed primarily to capital supply than to investment projects FDI can only be effective if it is directed toward improving and expanding managerial and labour skills.

Finally, the most effective strategy for attracting foreign investment is to make the Nigerian economy very attractive to home investors at the beginning.

\section{Policy Recommendations}


The study therefore makes the following recommend- dations to policy makers and government for attracting foreign investors in other to give their contribution for the Nigerian growth and development.

- The Nigerian government should ensure the transparency of the operations of foreign investors within the economy by government of Nigeria and to encourage inflows of FDI.

- Government should simplify and improved the screening process of FDI e.g. any foreign investment that brings about significant contribution to national income can be given priority.

- Friendly economic policies and business environment need to be put in place in order to attract FDI into all sectors of the economy.

- Good and stable infrastructural facilities such as electricity, roads, water etc are highly needed to attract FDI in Nigerian.

- Nigerian government should carry out full liberalization of all sectors of the economy for foreign investors to be attracted.

- Issues of security and corruption should permanently address for any foreign investment to come to Nigeria.

\section{REFERENCES}

[1] Alfaro, L., C. Arendam, K. O. Sebrem, S. Selin (2006) "How Does Foreign Direct Investment PromoteEconomic Growth?" Exploring the Effects of Financial Markets on Linkages. NBER workingpaper No 12522

[2] Akinlo, A. E. (2004) "Foreign Direct Investment and Growth in Nigeria: An Empirical Investigation." Journal of Policy Modeling. (26) 5 627-639

[3] Boyd, J. H., and B. D. Smith (1992). "Intermediation and the Equilibrium Allocation of InvestmentCapital: Implications for Economic Development.” Journal of Monetary Economics 30 409-432

[4] Noorzoy M. S. (1979) "Flows of Direct Investment and their Effects on Investment in Canada." Economic Letters, 2(3) $357-61$

[5] Nunnenkamp, P. and J. Spatz (2003) "Foreign Direct Investment and Economic Growth in DevelopingCountries: How Relevant are Host - country and Industry characteristics?" Kiel working paper no. 1176

[6] Otepola A. (2002) "Foreign Direct Investment as a factor of Economic Growth in Nigeria." AfricaInstitute for Economic Development and Planning (IDEP), Dakar, Seregal

[7] Oyejide T. A. (2005) Capital Flows and Economic Transformation: A Conceptual Framework on Proceedings of Central Bank of Nigeria 5th Annual Monetary Policy Conference with the theme "Capital Flows and Economic Transformation in Nigeria." Held at the CBN Conference Hall, Abuja. November 10th to 11th. The Economist Intelligence Unit (2008) CountryData-Annual Time Series 1980-2007
[8] World Bank (1996) World Debt Tables: External Finance for Developing Countries 1 (Analysis andSummary Tables). Washington D.C. The World Bank

[9] Adelegan, J.O. (2000): "Foreign direct investment and economic growth in Nigeria: A seemingly unrelated model". African Review of Money, Finance and Banking, Supplementary issue of "Savings and Development" 2000. Milan. pp.5-25

[10] Akinlo, A.E. (2004): "Foreign direct investment and growth in Nigeria: An empirical investigation".Journal of Policy Modeling, 26, pp. 627-39

[11] Aluko, S.A. (1961): "Financing economic development in Nigeria". The Nigerian Journal of Economic and Social Studies, 3(1), pp. 39-67

[12] Ayanwale, A. B. (2007): "FDI and Economic Growth: Evidence from Nigeria". AERC Research Paper 165. African Economic Research Consortium, Nairobi

[13] Ayanwale, A.B. and Bamire, A.S. (2001): "The Influence of FDI on Firm Level Productivity of Nigeria's Agro/ Agro-Allied Sector". Final Report Presented to the African Economic Research Consortium, Nairobi

[14] Barrell, R., \& Pain, N. (1997): Foreign direct investment, technological change, and economic growth within Europe. The Economic Journal, 107, 1770-1786

[15] Blomström, M. (1986): "Foreign Investment and Productive Efficiency: the Case of Mexico", Journal of Industrial Economics, $15,97-110$

[16] Blomström, M. and Persson, H. (1983): "Foreign Investment and Spillover Efficiency in an Underdeveloped Economy: Evidence from the Mexican Manufacturing Industry", World Development, 11, 493-501

[17] Blomström, M. and Wolf, E. (1994): "Multinational Corporations and Productivity Convergence in Mexico". In W. Baumol, R. Nelson and E. Wolf (Eds.) Convergence of Productivity: Cross-National Studies and Historical Evidence. Oxford: Oxford University Press

[18] Brown, C.V. (1962): "External Economies and Economic Development". The Nigerian Journal of Economic and Social Studies, 4(1): pp. 16-22

[19] Calderón, A., Mortimore, M. and Peres (1996): "Foreign Investment as a Source of International Competitiveness". In Dunning J.H. and Narula (eds.) Catalyst for Economic Restructuring. Routledge, 241-279

[20] CBN (2007): Annual Economic Report. Central Bank of Nigeria

[21] CBN (2007): Statistical Bulletin. Central Bank of Nigeria, Volume 18

[22] Chenery, H. B. and Stout, A. (1966): "Foreign Assistance and Economic Development”. American Economic Review. 55, pp.679-733

[23] Chenery, H. B. and Watanabe, T. (1958): "International Comparisons of the structure of Production". Econometrica. 26, pp. 487-521. 17

[24] De Gregorio, Jose. (2003):."The role of Foreign Direct Investment and Natural Resources in Economic Development". 
Working Paper No 196. Central Bank of Chile, Santiago

[25] Dolan, Michael B. \& Brian W. Tomlin (1980): "First World-Third World Linkages: External Relations and Economic Development" International Organization, Vol. 34, No. 1. (Winter, 1980), pp. 41-63

[26] Edozien, E.G. (1968): "Linkages, direct foreign investment and Nigeria's Economic Development". The Nigerian Journal of Economic and Social Studies, 10 (2), pp. 119-203

[27] Goldberg, S. and Klein, W. (1998): "Foreign Direct Investment, Trade, and Real Exchange Rate Linkages in Developing Countries”. In Reuven Glick (ed.) Managing Capital Flows and Exchange Rates: Lessons from the Pacific Basin. Cambridge University Press

[28] Goldberg, S. and Klein, W. (1999) : "International Trade and Factor Mobility: an Empirical Investigation", NBER Working Paper No. 7196

[29] Herzer, D., Klasen, S., Nowak-Lehmann, D. F. (2006): "In search of FDI-led growth in developing countries: The way forward". Ibero American Institute for Economic Research

[30] Kokko, A., Tansini, R. and Zejan, M. (1996): "Local Technological Capability and Spillovers from FDI in the Uruguayan Manufacturing Sector", Journal of Development Studies 34, 602- 611

[31] Obinna, O.E. (1983): "Diversification of Nigeria's External Finances through Strategic Foreign Direct Investment". Ni- gerian Economic Society Annual Conference Proceedings, Jos, 13-16th May

[32] OECD (1998) Foreign Direct Investment and Economic Development: Lessons from Six Emerging Economies. Paris

[33] Okodua, H (2009): "Foreign Direct Investment and Economic Growth: Co-Integration and Causality Analysis of Nigeria", The African Finance Journal, Volume 11, Part 1

[34] Otepola, A. (2002): "FDI as a Factor of Economic Growth in Nigeria. Dakar, Senega". African Institute for Economic Development and Planning (IDEP), May. Available online at: idep@unidep.org, http://www.unidep.org

[35] Oyinlola, O. (1995): "External Capital and Economic Development in Nigeria (1970-1991)". The Nigerian Journal of Economic and Social Studies, 37(2\&3), pp. 205-22

[36] Rodriguez-Clare, A. (1996): "Multinationals, Linkages, and Economic Development", The American Economic Review $86,852-873$

[37] Saltz, I. (1992): "The Negative Correlation between Foreign Direct Investment and Economic Growth in the Third World: Theory and Evidence". Rivista Internazionale di Scienze Economiche e Commerciali. 39(7), pp. 617-633

[38] UNCTAD (2006): World Investment Report, United Nations, New York

[39] UNCTAD (2007): Handbook of Statistics available on-line at (http://www.unctad.org) 